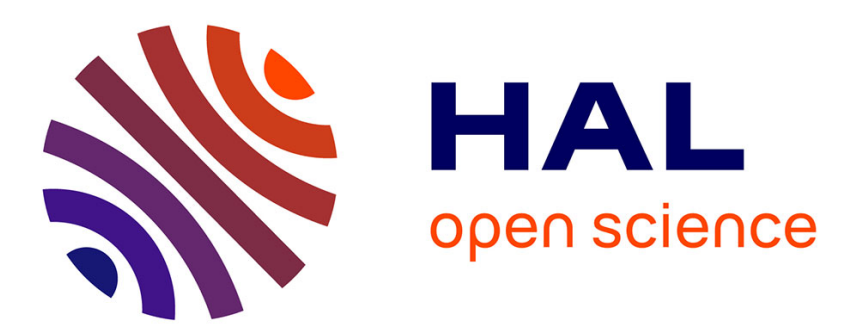

\title{
Ag-Ni bimetallic SiBEA zeolite as an efficient catalyst of hydrodechlorination of 1,2-dichloroethane towards ethylene
}

\author{
A Śrębowata, I Zielińska, R Baran, G Slowik, S Dzwigaj
}

\section{To cite this version:}

A Śrębowata, I Zielińska, R Baran, G Slowik, S Dzwigaj. Ag-Ni bimetallic SiBEA zeolite as an efficient catalyst of hydrodechlorination of 1,2-dichloroethane towards ethylene. Catalysis Communications, 2015, 69, pp.154-160. 10.1016/j.catcom.2015.06.009 . hal-01171840

\section{HAL Id: hal-01171840 \\ https://hal.sorbonne-universite.fr/hal-01171840}

Submitted on 6 Jul 2015

HAL is a multi-disciplinary open access archive for the deposit and dissemination of scientific research documents, whether they are published or not. The documents may come from teaching and research institutions in France or abroad, or from public or private research centers.
L'archive ouverte pluridisciplinaire HAL, est destinée au dépôt et à la diffusion de documents scientifiques de niveau recherche, publiés ou non, émanant des établissements d'enseignement et de recherche français ou étrangers, des laboratoires publics ou privés. 
Ag-Ni bimetallic SiBEA zeolite as an efficient catalyst of hydrodechlorination of 1,2dichloroethane towards ethylene

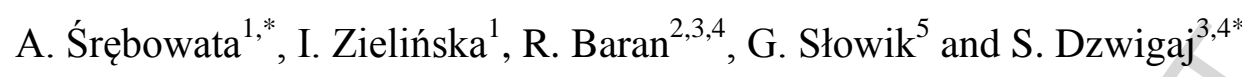

${ }^{1}$ Institute of Physical Chemistry, PAS, Kasprzaka 44/52, PL-01224 Warszawa, Poland,

${ }^{2}$ AGH University of Science and Technology al. A. Mickiewicza 30, 30-059 Krakow, Poland

${ }^{3}$ Sorbonne Universités, UPMC Univ Paris 06, UMR 7197, Laboratoire de Réactivité de Surface, F-75005, Paris, France

${ }^{4}$ CNRS, UMR 7197, Laboratoire de Réactivité de Surface, F-75005, Paris, France

${ }^{5}$ Faculty of Chemistry, Department of Chemical Technology, Maria Curie - Skłodowska University, Plac Marii Curie - Skłodowskiej 3, PL-20-031 Lublin, Poland

Figures: 5

Keywords: Ag, Ni, BEA, 1,2-dichloroethane, ethylene, hydrodechlorination

\section{*Corresponding authors}

Anna Srebowata, E-mail: $\quad$ asrebowata@ichf.edu.pl, $\quad$ Tel. 481223433320

Stanislaw Dzwigaj, E-mail : stanislaw.dzwigaj@upmc.fr, Fax : 33144272113 


\begin{abstract}
Dealuminated form of BEA zeolite with $\mathrm{Si} / \mathrm{Al}$ ratio of 1500 was used for synthesis $\mathrm{Ag}_{2.0} \mathrm{SiBEA}, \mathrm{Ni}_{2.0} \mathrm{SiBEA}$ and $\mathrm{Ag}_{2.0} \mathrm{Ni}_{2.0} \mathrm{SiBEA}$ by two-step postsynthesis method. The calcination of zeolite samples led to formation of well dispersed isolated mononuclear $\mathrm{Ag}(\mathrm{I})$ and $\mathrm{Ag}_{\mathrm{n}}{ }^{\delta+}$ clusters and a pseudo-tetrahedral $\mathrm{Ni}(\mathrm{II})$, incorporated in BEA framework as evidenced by DR UV-vis investigations. The treatment of samples in flowing $10 \% \mathrm{H}_{2} / \mathrm{Ar}$ stream gave small (average $3.1 \mathrm{~nm}$ ) and well dispersed metals nanoparticles. Reduced catalysts were investigated in 1,2-dichloroethane hydrodechlorination at atmospheric pressure, at low reaction temperature $(523 \mathrm{~K})$ with $\sim 100 \%$ of selectivity to ethylene, desired product of the reaction.
\end{abstract}




\section{Introduction}

The stability, activity and high selectivity toward desired product are the key factors for the design and preparation of catalysts for hydrodechlorination (HDC) and the essential issue for the industrial application of this technology [1,2]. Therefore, the finding of effective methods of synthesis HDC catalysts is still under investigation. Hydrodechlorination is known as structural sensitive reaction, but among the researchers opinions are divided on the effect of metal(s) dispersion and metal particle size on this process. Some of the scientists claim that higher metal particles size and smaller dispersion play the crucial role in activity and stability of HDC catalysts $[3,4]$. On the other hand, some of the literature data clearly show the beneficial role of excellent dispersed very small metal particles in hydrodechlorination process [5]. Our recent studies on nickel containing beta zeolite in conversion of 1,2dichloroethane brightly demonstrated the high stability, and high selectivity of very small $(\sim 1,5 \mathrm{~nm})$ nickel particles size [5]. In spite of earlier reports [6,7] the small metal particles did not deactivate during reaction and they are resistant to sintering [5]. As we have earlier shown [8] the application of dealuminated SiBEA zeolite with vacant T-atom sites played an important role on the formation stable, active and selective catalysts. Very interesting results were obtained also for bimetallic $\mathrm{Cu}-\mathrm{Ni}$ systems prepared by two-step postsynthesis method [9] that consist, in the first step, dealumination of BEA zeolite by treatment with nitric acid and then, in the second step, incorporation of metal into the framework of BEA zeolite by their reaction with silanol groups of vacant T-atom sites of resulted SiBEA zeolite. The reduction of well dispersed metal species with $\mathrm{H}_{2}$ led to formation of small metal nanoparticles in extra-framework position. Careful investigations have shown very good activity of bimetallic $\mathrm{Cu}-\mathrm{Ni}$ zeolite catalysts containing small and well dispersed $\mathrm{Ni}(0)$ and $\mathrm{Cu}(0)$ nanoparticles in hydrodechlorination of 1,2-dichloroethane and high selectivity to ethylene [9]. Inspired by our earlier work $[9,10]$ we would like to investigate the effect of 
two-step postsynthesis method of preparation on catalytic properties of silver and nickel loaded BEA zeolite in hydrodechlorination of 1,2-dichloroethane. Until now only the addition of silver to Pd in HDC of 1,2-dichloroethane were successfully investigated [11,12]. Addition of silver to palladium containing catalysts has reduced strong hydrogenating properties of palladium and led to increasing of the selectivity to ethylene (desired product 1,2-DCA HDC). Therefore, we have expected to observe the same phenomenon in the case of Ag-Ni system.

\section{Experimental}

\subsection{Catalysts preparation}

A tetraethylammonium BEA (TEABEA) $(\mathrm{Si} / \mathrm{Al}=17)$ zeolite provided by RIPP (China) was calcined for $15 \mathrm{~h}$ at $823 \mathrm{~K}$ to remove template. Organic-free BEA zeolite was separated into two portions. The first, portion of $2 \mathrm{~g}$ of TEABEA was treated with $200 \mathrm{ml}$ of $13 \mathrm{~mol} \cdot \mathrm{L}^{-}$ ${ }^{1}$ nitric acid solution $(353 \mathrm{~K}, 4 \mathrm{~h})$ to obtain dealuminated SiBEA zeolite and then washed several times with distilled water and dried at $363 \mathrm{~K}$ overnight. Results of chemical analysis indicate that only traces of $\mathrm{Al}$ remain in SiBEA after nitric acid treatment with $\mathrm{Si} / \mathrm{Al}$ ratio of 1500.

$\operatorname{Ag}_{x} \operatorname{SiBEA}(x=2 \mathrm{Ag} w t \%), \mathrm{Ni}_{\mathrm{x}} \operatorname{SiBEA}\left(\mathrm{x}=2 \mathrm{Ni}\right.$ wt $\%$ ) or $\operatorname{Ag}_{\mathrm{x}} \mathrm{Ni}_{\mathrm{y}} \operatorname{SiBEA}(\mathrm{x}=2 \mathrm{Ag}$ wt $\%$ and $\mathrm{y}=2 \mathrm{Ni}$ wt $\%$ ) were prepared by co-impregnation of $2 \mathrm{~g}$ of SiBEA with $\mathrm{Ag}\left(\mathrm{NO}_{3}\right)_{2} \cdot 6 \mathrm{H}_{2} \mathrm{O}$ or $\mathrm{Ni}\left(\mathrm{NO}_{3}\right)_{2} \cdot 6 \mathrm{H}_{2} \mathrm{O}$ and $\mathrm{Ag}\left(\mathrm{NO}_{3}\right)_{2} \cdot 6 \mathrm{H}_{2} \mathrm{O}$ solutions, respectively, with appropriate concentration of $\mathrm{Ag}$ and Ni. Firstly, all suspensions were stirred for $24 \mathrm{~h}$ at $298 \mathrm{~K}$ in excess solvent using $200 \mathrm{~mL}$ of the precursor solutions. Then, the suspensions were stirred in rotevaporator under vacuum of a water pump for $2 \mathrm{~h}$ in air at $333 \mathrm{~K}$ until complete evaporation of water. The catalysts obtained in this ways are labeled $\mathrm{Ag}_{2.0} \mathrm{SiBEA}, \mathrm{Ni}_{2.0} \mathrm{SiBEA}$ and $\mathrm{Ag}_{2.0} \mathrm{Ni}_{2.0} \mathrm{SiBEA}$. All these materials were calcined in static air at $773 \mathrm{~K}$ for $3 \mathrm{~h}$ and labeled $\mathrm{C}-\mathrm{Ag}_{2.0} \mathrm{SiBEA}, \mathrm{C}-\mathrm{Ni}_{2.0} \mathrm{SiBEA}$ and $\mathrm{C}-\mathrm{Ag}_{2.0} \mathrm{Ni}_{2.0} \mathrm{SiBEA}$, respectively. Then, a portion of these materials were reduced at $873 \mathrm{~K}$ for $3 \mathrm{~h}$ in flowing $10 \% \mathrm{H}_{2} / \mathrm{Ar}$ to obtain red-C- $\mathrm{Ag}_{2.0} \mathrm{SiBEA}$, 
red-C-Ni ${ }_{2.0} \mathrm{SiBEA}$ and red-C- $\mathrm{Ag}_{2.0} \mathrm{Ni}_{2.0} \mathrm{SiBEA}$, where $\mathrm{C}$ - stands for calcined and red - for reduced. These catalysts after kinetic run were labeled with additional prefix spent-, as spentred-C-Ag ${ }_{2.0} \mathrm{SiBEA}$, spent-red-C-Ni ${ }_{2.0} \mathrm{SiBEA}$ and spent-red-C- $\mathrm{Ag}_{2.0} \mathrm{Ni}_{2.0} \mathrm{SiBEA}$.

\subsection{Catalyst characterization}

Chemical analysis was performed at room temperature on SPECTRO X-Lab Pro apparatus.

DR UV-vis spectra were recorded at ambient atmosphere on a Cary 5000 Varian spectrometer equipped with a double integrator with polytetrafluoroethylene as reference.

Temperature - programmed reduction (TPR) for both of the catalysts, after calcination step, were carried out using the glass-flow system. TPR runs were performed in flowing $10 \%$ $\mathrm{H}_{2} / \mathrm{Ar}\left(25 \mathrm{~cm}^{3} \mathrm{~min}^{-1}\right)$, ramping the temperature at $10 \mathrm{~K} \mathrm{~min}^{-1}$ and using a Gow-Mac thermal conductivity detector (TCD). Injections of known amounts of hydrogen into the hydrogenargon flow were provided for calibration (before and after each TPR run).

Chemisorption measurements of $\mathrm{H}_{2}$ and $\mathrm{CO}$ using a conventional static method were carried out with a Micromeritics ASAP 2020 Chem instrument. Prior to chemisorption measurement $0.1 \mathrm{~g}$ of $\mathrm{C}-\mathrm{Ag}_{2.0} \mathrm{Ni}_{2.0} \mathrm{SiBEA}$ were reduced in flowing $10 \% \mathrm{H}_{2} / \mathrm{Ar}\left(25 \mathrm{~cm}^{3} \mathrm{~min}^{-1}\right)$, ramping the temperature from room to $873 \mathrm{~K}$ (at $10 \mathrm{~K} \mathrm{~min}^{-1}$ ) and kept at $873 \mathrm{~K}$ for $3 \mathrm{~h}$. Then the catalysts were cooled down to the room temperature and connected with ASAP 2020 instrument. Next, the samples were heated in flowing $\mathrm{He}$ at $383 \mathrm{~K}$ for $30 \mathrm{~min}$ with an additional evacuation for $10 \mathrm{~min}$. At this temperature, the helium flow was switched for the hydrogen flow and the temperature increased $\left(10 \mathrm{~K} \mathrm{~min}^{-1}\right)$ to $653 \mathrm{~K}$ and the samples were reduced for $120 \mathrm{~min}$, subsequently outgassed for $30 \mathrm{~min}$, and finally cooled to $343 \mathrm{~K}$ with 30 min evacuation. The hydrogen adsorption isotherm was established. After evacuation at 343 $\mathrm{K}$, a second $\mathrm{H}_{2}$ isotherm was performed. The gas uptake was obtained by extrapolating to zero pressure the linear portion of the isotherm above the saturation pressure. The first hydrogen 
isotherm provided the sum of the reversibly and irreversibly adsorbed hydrogen while the second isotherm represented only the reversibly adsorbed hydrogen. The amount of chemisorbed hydrogen was given by the difference. After the second isotherm, the same sample was heated in $\mathrm{H}_{2}$ at $653 \mathrm{~K}$ and outgassed at this temperature for $30 \mathrm{~min}$. Then, the $\mathrm{H}_{2}$ flow was switched for He and the sample was cooled down to the temperature $298 \mathrm{~K}$ with additional 10 minutes evacuation. $\mathrm{CO}$ adsorption isotherm was measured at room temperature and was established similarly like in the case of hydrogen adsorption procedure. The metal dispersion (D, in \%), and metal particle size (d, in $\mathrm{nm})$ were determined from both the $\mathrm{H}_{2}$ and $\mathrm{CO}$ chemisorption data, assuming that $\mathrm{H} / \mathrm{Ni}_{\mathrm{s}}$ ratio equals $1[13,14]$ and $\mathrm{CO} / \mathrm{Ni}$ equals 0,5 at room temperature. $[15,16]$.

TEM studies for the catalysts after reduction step were carried out using JEOL JEM100CXII electron microscope operated at an acceleration voltage of $100 \mathrm{keV}$. The samples were prepared by their dispersing in pure alcohol using ultrasonic cleaner and putting a drop of this suspension on carbon films on copper grids. Independent STEM and HRTEM experiments were carried out on the electron microscope Titan G2 60-300 kV FEI Company, equipped with: field emission gun (FEG), monochromator, three condenser lenses system, the objective lens system, image correction (Cs-corrector), HAADF detector and EDS spectrometer (Energy Dispersive X -Ray Spectroscopy) EDAX Company with detector $\mathrm{Si}(\mathrm{Li})$. Microscopic studies of the catalysts were carried out at an accelerating voltage of the electron beam equal to $300 \mathrm{kV}$. The mapping was carried out in the STEM mode by collecting point by point of EDS spectrum of each of the corresponding pixels in the map. The collected maps were presented in the form of a matrix of pixels with the color mapped significant element and the intensity corresponding to the percentage of the element.

X-ray driffractograms (XRD) for red-C-Ag $\mathrm{A}_{2.0} \mathrm{SiBEA}$, red-C- $\mathrm{Ag}_{2.0} \mathrm{Ni}_{2.0} \mathrm{SiBEA}$ and spentred-C- $\mathrm{Ag}_{\mathrm{x}} \mathrm{SiBEA}$, spent-red-C- $\mathrm{Ag}_{\mathrm{x}} \mathrm{Ni}_{\mathrm{y}} \mathrm{SiBEA}$ were recorded on Geigerflex Rigaku-Denki 
(Japan) diffractometer with nickel filtered and $\mathrm{CuK} \alpha$ radiation. Data acquisitions for sample after reduction step and after kinetic run were recorded in the $2 \theta$ range of 5 - $90^{\circ}$ with step of $0.02^{\circ}$

\subsection{Catalysts activity measurements}

The reactions of hydrodechlorination of 1,2-dichloroethane (1,2-DCE, HPLC grade, 99.8\% pure from Sigma-Aldrich, Germany) were carried out at atmospheric pressure, in a glass flow reactor equipped with fritted disk to place a catalyst charge. Prior to reaction, $0.2 \mathrm{~g}$ of the catalyst, after calcination step at $773 \mathrm{~K}$, was reduced in flowing $10 \% \mathrm{H}_{2} / \mathrm{Ar}\left(25 \mathrm{~cm}^{3}\right.$ $\left.\min ^{-1}\right)$, ramping the temperature from room temperature to $873 \mathrm{~K}\left(10 \mathrm{~K} \mathrm{~min}^{-1}\right)$ and kept at 873 $\mathrm{K}$ for $3 \mathrm{~h}$. After this time, the catalysts were cooled to $523 \mathrm{~K}$, then contacted with the flowing reaction mixture $\left(\mathrm{H}_{2}+\mathrm{Ar}+1,2-\mathrm{DCA}\right)$ of $2.86 \times 10^{-5} \mathrm{~mol} \mathrm{~s}^{-1}\left(42 \mathrm{~cm}^{3} \mathrm{~min}^{-1}\right)$ The contact time was of $0.7 \mathrm{~s}$ and the space velocity (SV) of $0.0035\left(\mathrm{~m}^{3} \mathrm{~kg}^{-1} \mathrm{~s}^{-1}\right) \cdot 1,2$-DCE was provided from a saturator kept at $273 \mathrm{~K}$ to give the partial pressure of 1,2-dichloroethane of $2.9 \mathrm{kPa}$. The partial pressure ratio $\mathrm{pH}_{2} / \mathrm{p} 1,2-\mathrm{DCE}$ was $1: 1$. The flows of $\mathrm{H}_{2}$ and $\mathrm{Ar}$, were fixed by using Bronkhorst Hi-Tec mass flow controllers. The reaction was followed by gas chromatography, using a HP5890 series II gas chromatograph with FID, a 5 \% Fluorcol/Carbopack B column (10 ft) from Supelco. The results of GC analysis were elaborated using HP Chemstation. The total FID signal from the first two analyses was similar to that observed in subsequent GC analyses.

\section{Results and discussion}

\subsection{Diffuse reflectance $U V$-vis investigation}

In the DR UV-vis spectrum of $\mathrm{C}-\mathrm{Ni}_{2.0} \mathrm{SiBEA}$ (Fig. 1) the bands at 460 and $555 \mathrm{~nm}$ are related to $\mathrm{Ni}(\mathrm{II})$ in tetrahedral or strongly distorted tetrahedral coordination and correspond to oxygen-tetrahedral $\mathrm{Ni}(\mathrm{II})$ charge transfer transitions [17,18]. DR-UV vis spectrum of C- 
$\mathrm{Ag}_{2.0} \mathrm{SiBEA}$ (Fig. 1) contains characteristic band at $214 \mathrm{~nm}$, strongly related to the charge transfer transition between $4 \mathrm{~d}^{10}$ and $4 \mathrm{~d}^{9} 5 \mathrm{~s}^{1}$ level of highly dispersed mononuclear $\mathrm{Ag}(\mathrm{I})$, in line with earlier reports for Ag-MFI, $\mathrm{Ag}^{+} / \mathrm{ZSM}-5$ and AgBEA zeolites, or $\mathrm{Ag} / \mathrm{Al}_{2} \mathrm{O}_{3},[18-22]$. Additionally, presence of the bands at 265 and $420 \mathrm{~nm}$ in the case of C- $\mathrm{Ag}_{2.0} \mathrm{SiBEA}$ may be the consequence of partial reduction and agglomeration of $\mathrm{Ag}^{+}$to $\mathrm{Ag}_{\mathrm{n}}{ }^{\delta+}$ clusters under calcination condition and the presence of silver nanoparticles.

For C-Ag ${ }_{2.0} \mathrm{Ni}_{2.0} \mathrm{SiBEA}($ Fig. 1) the band at $214 \mathrm{~nm}$ related to the charge transfer transition between $4 d^{10}$ and $4 d^{9} 5 s^{1}$ level of highly dispersed mononuclear $\mathrm{Ag}(\mathrm{I})$ is present as well as the

band at $265 \mathrm{~nm}$ attributed to $\mathrm{Ag}_{\mathrm{n}}{ }^{\delta+}$ clusters. In addition, the bands present between $450-635$ $\mathrm{nm}$ may be related to $\mathrm{Ni}(\mathrm{II})$ in tetrahedral and pseudo-tetrahedral coordination and correspond to oxygen-tetrahedral $\mathrm{Ni}(\mathrm{II})$ charge transfer transition $[17,18]$ indicating that nickel in $\mathrm{C}$ $\mathrm{Ag}_{2.0} \mathrm{Ni}_{2.0} \mathrm{SiBEA}$ is mainly present as pseudo-tetrahedral isolated centers.

\subsection{Temperature - programmed reduction results}

Temperature-programmed reduction experiments were carried out to determine the reducibility of silver and silver and nickel in C- $\mathrm{Ag}_{2.0} \mathrm{SiBEA}$ and $\mathrm{C}-\mathrm{Ag}_{2.0} \mathrm{Ni}_{2.0} \mathrm{SiBEA}$ zeolites, respectively. As shown in Fig. 2 TPR profile for $\mathrm{C}-\mathrm{Ag}_{2.0} \mathrm{SiBEA}$ contains four reduction peaks. The low intense reduction peaks at 312 and $363 \mathrm{~K}$ could be assigned to reduction of well dispersed silver oxides, in agreement with earlier works on silver based catalysts [23,24]. Two reduction peaks at 645 and $744 \mathrm{~K}$ may be attributed to reduction of excellent dispersed silver species, most probably present $\mathrm{C}-\mathrm{Ag}_{2.0} \mathrm{SiBEA}$ as mononuclear isolated $\mathrm{Ag}(\mathrm{I})$.

The TPR pattern of $\mathrm{C}-\mathrm{Ni}_{2.0} \mathrm{SiBEA}$ (Fig. 2) contains three peaks present at 730, 650 and $845 \mathrm{~K}$. The main signals at $730 \mathrm{~K}$ and $845 \mathrm{~K}$ suggests that nickel in $\mathrm{C}-\mathrm{Ni}_{2.0} \mathrm{SiBEA}$ is well dispersed as two kinds of isolated $\mathrm{Ni}(\mathrm{II})$ pseudo-tetrahedral species, strongly bound to SiBEA matrix $[25,26]$. Appearance of reduction peak at $650 \mathrm{~K}$ may be explained by the presence in 
$\mathrm{C}-\mathrm{Ni}_{2.0} \mathrm{SiBEA}$ small amount of octahedral $\mathrm{Ni}(\mathrm{II})$ species, easier reduced to $\mathrm{Ni}(0)$ than pseudotetrahedral $\mathrm{Ni}(\mathrm{II})$ one.

In TPR pattern of $\mathrm{C}-\mathrm{Ag}_{2.0} \mathrm{Ni}_{2.0} \mathrm{SiBEA}$ five peaks are present. The signals in the range of $618-672 \mathrm{~K}$ are due to the presence of nickel species in pseudo-tetrahedral coordination. The shift of the peaks to lower temperatures than that observed for $\mathrm{C}-\mathrm{Ni}_{2.0} \mathrm{SiBEA}$ in - our earlier work [9], may be caused by present of silver species, that slightly change of nickel environment and/or lead to formation of silver-nickel alloys. The presence of the TPR peaks corresponding to reduction of well dispersed silver oxides at higher temperature (352 and 390 $\mathrm{K})$ than those observed for $\mathrm{C}-\mathrm{Ag}_{2.0} \mathrm{SiBEA}$, suggests also about the interaction between silver and nickel in $\mathrm{C}-\mathrm{Ag}_{2.0} \mathrm{Ni}_{2.0} \mathrm{SiBEA}$. Moreover, the reduction peak observed for $\mathrm{C}$ $\mathrm{Ag}_{2.0} \mathrm{Ni}_{2.0} \mathrm{SiBEA}$ at $744 \mathrm{~K}$ confirms that in this sample isolated mononuclear $\mathrm{Ag}(\mathrm{I})$ are present.

\subsection{TEM investigation}

Transmission electron microscopy images of red-C-Ag ${ }_{2.0} \mathrm{SiBEA}$ and red-C$\mathrm{Ag}_{2.0} \mathrm{Ni}_{2.0} \mathrm{SiBEA}$ are shown in Fig. 3a. Both, TEM images and histograms show rather uniform distribution of metallic nanoparticles for both red-C-Ag${ }_{2.0} \mathrm{SiBEA}$ and red-C$\mathrm{Ag}_{2.0} \mathrm{Ni}_{2.0} \mathrm{SiBEA}$ with the vast amount of average nanoparticles size of 2-3 nm and 3-4 nm, respectively. In relation to our earlier studies concerning red-C-Cu $\mathrm{Cu}_{2.0} \mathrm{Ni}_{2.0} \mathrm{SiBEA}$ [10] in hydrodechlorination of 1,2-dichloroethane, very small nanoparticles size obtained for bimetallic Ag-Ni catalyst could suggest that two-step postsynthesis method used for preparation of red-C- $\mathrm{Ag}_{2.0} \mathrm{Ni}_{2.0} \mathrm{SiBEA}$ allowed to formation rather separate $\mathrm{Ag}(0)$ and $\mathrm{Ni}(0)$ nanoparticles than bimetallic alloys.

To confirm this statement the independent STEM and HRTEM experiments were realised. They confirmed our suppositions. Fig. 3b shows the typical STEM image and EDS- 
elemental mapping of $\mathrm{Ag}$ (violet) and $\mathrm{Ni}$ (orange) for red-C- $\mathrm{Ag}_{2.0} \mathrm{Ni}_{2.0} \mathrm{SiBEA}$. HRTEM images reveal rather uniform distribution of silver and nickel nanoparticles for red-C$\mathrm{Ag}_{2.0} \mathrm{Ni}_{2.0} \mathrm{SiBEA}$ zeolite with average metals particles size of $3.1 \mathrm{~nm}$. Bimetallic Ag-Ni catalyst contains separately located and very small $(\sim 1.5 \mathrm{~nm}) \mathrm{Ni}$ nanoparticles and bigger silver nanoparticles located in the direct vicinity with nickel. This phenomenon could confirm the partial formation of $\mathrm{Ag}-\mathrm{Ni}$ alloys.

\subsection{Chemisorption results}

Chemisorption measurements of $\mathrm{H}_{2}$ and $\mathrm{CO}$ using a conventional static method were effective way to determine dispersion of nickel in red-C- $\mathrm{Ag}_{2.0} \mathrm{Ni}_{2.0} \mathrm{SiBEA}$. For bimetallic $\mathrm{Ag}$ Ni sample rather high nickel dispersion was measured (30.0\% from $\mathrm{H}_{2}$ adsorption and 37.4\% from $\mathrm{CO}$ adsorption). The lower adsorption capability for bimetallic Ag-Ni catalyst than for monometallic nickel sample (55\% from $\mathrm{H}_{2}$ adsorption and $60 \%$ from $\mathrm{CO}$ adsorption [5]) confirms the formation of Ag-Ni alloys. According to literature [16] very high compatibility of the results obtained by $\mathrm{H}_{2}$ and $\mathrm{CO}$ chemisorption was observed.

\subsection{Catalytic activity of Ag-Ni catalysts}

Figure 4 shows the time on stream behaviour of red-C- $\mathrm{Ag}_{2.0} \mathrm{Ni}_{2.0} \mathrm{SiBEA}$ catalyst in comparison with the results obtained for monometallic silver and monometallic nickel samples. Red-C-Ag ${ }_{2.0}$ SiBEA exhibits approximately halved lower activity in hydrodechlorination of 1,2-dichloroethane than monometallic nickel and bimetallic Ag-Ni material. However, as we reported in our recent work [5], SiBEA zeolite is practically inactive in reaction condition, so it is worth noting that the measurable activity of monometallic silver in 1,2-dichloroethane HDC ( $4 \%$ of conversion) is rather unique. Earlier studies on silver catalysts in hydrodechlorination have shown that independently on the synthesis method (conventional impregnation [27], sol - gel method [28] or 
photodeposition [29] and regardless of the kind of the support ( $\mathrm{C}, \mathrm{SiO}_{2}$ and $\mathrm{TiO}_{2}$ ) [27-29]. only negligible 1,2-dichloroethane conversion was identified for monometallic silver catalysts, or silver catalysts were completely inactive in hydrodechlorination. This phenomenon was ascribed to the rapid and irreversible deactivation of $\mathrm{Ag}$ sites by chlorine during the HDC process. The measurable activity obtained for red-C-Ag ${ }_{2.0} \mathrm{SiBEA}$ could be the effect application of two-step postsynthesis procedure as the method of synthesis very small silver particles capable to promote electron transfer from metal to the support. The similar phenomenon was observed for very small $\mathrm{Pd}$ particles in hydrodechlorination of chlorobenzene [30]. The crucial role in activity of red-C- $\mathrm{Ag}_{2.0} \mathrm{SiBEA}$ plays also the dealuminated form of BEA zeolite as the support for Ag species. This zeolite obtained by dealumination of parent BEA material contains vacancies, which may be the cause of formation of electron deficient $\mathrm{Ag}$ species, similarly like in case $\mathrm{Au} / \mathrm{Fe}_{2} \mathrm{O}_{3}$ in hydrodechlorination of 2,4-dichlorophenol [31]. The cationic $\mathrm{Ag}$ and/or $\mathrm{Ag}_{\mathrm{n}}{ }^{\delta+}$ clusters thus formed are resistant to deactivation by adsorbed chlorine and well-dispersed red-C$\mathrm{Ag}_{2.0} \mathrm{SiBEA}$ zeolite catalyst remains active during the reaction.

On the other hand red-C-Ni ${ }_{2.0} \mathrm{SiBEA}$ exhibits approximately two times higher activity than silver catalyst and $\sim 90 \%$ of selectivity towards ethylene - desired product of hydrodechlorination of 1,2-dichloroethene (Fig. 4). Whereas red-C- $\mathrm{Ag}_{2.0} \mathrm{Ni}_{2.0} \mathrm{SiBEA}$ shows only slightly lower activity than red-C-Ni $i_{2.0} \mathrm{SiBEA}$, (Fig. 4). So, the addition of nickel to $\mathrm{Ag}$ plays the beneficial major role in increasing of red-C- $\mathrm{Ag}_{2.0} \mathrm{Ni}_{2.0} \mathrm{SiBEA}$ activity, while maintaining $100 \%$ selectivity to ethylene.

Due to the fact that both nickel and silver nanoparticles supported on dealuminated form of BEA are active in 1,2-DCE HDC, and both of them show very high selectivity toward desired product, we suppose that $\mathrm{Ni}(0)$ can plays dual role in red-C- $\mathrm{Ag}_{2.0} \mathrm{Ni}_{2.0} \mathrm{SiBEA}$ zeolite during conversion of 1,2-DCE to ethylene. So, it probably serves as the hydrogen source (in 
the case of $\operatorname{Ag}(0)-\mathrm{Ni}(0)$ alloys $)$ and as separately located nickel active sites in reaction with 1,2-dichloroethane.

According to the results of the calculations published by Pirard at al. [28] hydrodechlorination of 1,2-dichloroethane correspond to a Langmuir-Hinshelwood model including two types of active sites. It could mean that hydrodechlorination of 1,2dichloroethane into ethylene on red-C- $\mathrm{Ag}_{2.0} \mathrm{Ni}_{2.0} \mathrm{SiBEA}$ zeolite occurs both on $\operatorname{Ag}(0)$ and $\mathrm{Ni}(0)$ sites through dissociative adsorption with successive breaking of the two $\mathrm{C}-\mathrm{Cl}$ bonds and desorption of ethylene. However, reaction on $\operatorname{Ag}(0)$, independently on used support, usually leads to irreversible adsorption on chlorine atoms. Therefore, in practice, the activity of monometallic silver has been never observed. So Therefore, the presence of $\mathrm{Ni}(0)$ as the source of the atomic hydrogen in $\mathrm{Ag}-\mathrm{Ni}$ alloys could prevent deactivation of $\operatorname{Ag}(0)$ sites. It means that the simultaneously introduction of silver and nickel ions in dealuminated BEA structure in the second step of postsynthesis procedure allows obtaining after reduction of bimetallic Ag-Ni catalyst with well dispersed, separated $\operatorname{Ag}(0)$ and $\mathrm{Ni}(0)$ nanoparticles and Ag-Ni alloys that have higher selectivity to ethylene than monometallic nickel catalyst.

\section{6. $X$-ray diffraction investigation}

The XRD patterns of red-C- $\mathrm{Ag}_{2.0} \mathrm{SiBEA}$ and red-C- $\mathrm{Ag}_{2.0} \mathrm{Ni}_{2.0} \mathrm{SiBEA}$ (Fig.5) are typical of BEA structure as was observed earlier [5], so the incorporation of nickel and silver into zeolite structure did not damage the BEA matrix. The absence of diffraction lines of $\mathrm{Ni}$ and $\mathrm{NiO}$ in bimetallic sample indicates a good dispersion of nickel species, what is in agreement with our earlier studies [5,10]. On the other hand, the presence of diffraction lines characteristic for $\mathrm{Ag}(0)$ in red-C- $\mathrm{Ag}_{2.0} \mathrm{SiBEA}$ and red-C- $\mathrm{Ag}_{2.0} \mathrm{Ni}_{2.0} \mathrm{SiBEA}$ (Fig.5 circles)

indicates the average silver diameter based on ( $\left.\begin{array}{lll}1 & 1 & 1\end{array}\right)$ XRD line broadening as $6 \mathrm{~nm}$. Moreover, comparative study between XRD results obtained for red-C- $\mathrm{Ag}_{2.0} \mathrm{SiBEA}$, 
red-C- $\mathrm{Ag}_{2.0} \mathrm{Ni}_{2.0} \mathrm{SiBEA}$, spent-red-C- $\mathrm{Ag}_{2.0} \mathrm{SiBEA}$ and spent-red-C- $\mathrm{Ag}_{2.0} \mathrm{Ni}_{2.0} \mathrm{SiBEA}$ have shown that $\mathrm{AgCl}$ is formed on both catalysts under reaction conditions (Fig. 5 - triangles) with average $\mathrm{AgCl}$ diameter based on $\left(\begin{array}{lll}0 & 0 & 2\end{array}\right)$ XRD line broadening - $9 \mathrm{~nm}$. It should be stressed that, in case of spent-red-C- $\mathrm{Ag}_{2.0} \mathrm{Ni}_{2.0} \mathrm{SiBEA}$ there has been only partial transformation of $\mathrm{Ag}(0)$ into $\mathrm{AgCl}$. This phenomenon may confirm that coexistence of $\mathrm{Ag}(0)$ and $\mathrm{Ni}(0)$ in red-C- $\mathrm{Ag}_{2.0} \mathrm{Ni}_{2.0} \mathrm{SiBEA}$ catalyst partially blocks deactivation of $\mathrm{Ag}(0)$ by chlorine species. On the other hand, the formation of significant amounts of $\mathrm{AgCl}$ during HDC reaction could-suggest about confirms the presence in red-C- $\mathrm{Ag}_{2.0} \mathrm{Ni}_{2.0} \mathrm{SiBEA}$ of both separately located $\mathrm{Ni}(0)$ and $\mathrm{Ag}(0)$ nanoparticles and $\mathrm{Ag}-\mathrm{Ni}$ alloys.

\section{Conclusions}

The two-step postsynthesis method used for catalyst preparation is an excellent way to obtain Ag-Ni zeolite materials with high level of metal dispersion and good catalytic properties.

Both, red-C- $\mathrm{Ag}_{2.0} \mathrm{SiBEA}$ and red-C- $\mathrm{Ag}_{2.0} \mathrm{Ni}_{2.0} \mathrm{SiBEA}$ catalysts are active in hydrodechlorination of 1,2-dichloroethane with $100 \%$ of selectivity toward ethylene desired product of the reaction.

Addition of nickel to silver catalyst leads to increasing of the overall conversion in HDC and protects silver species against irreversible adsorption chlorine species and formation of $\mathrm{AgCl}$.

\section{Acknowledgements}

Project funded by the Foundation for Polish Science, POMOST/2011-4/11 co-financed by the EU European Regional Development Fund (AŚ, IZ, SD). Special thanks for Sandra Casale 
from Laboratoire de Réactivité de Surface, Sorbonne Universités, UPMC Univ Paris 06 for

TEM measurements. Special thanks for Dmytro Lisovytskiy from Institute of Physical Chemistry, PAS for XRD measurements.

\section{References}

1. L.E. Manzer, Catal. Today 13 (1992) 13-22

2. L.E. Manzer, V.N. Rao, Adv. Catal. 39 (1993) 329-350

3. M. Martin-Martinez, A. Álvarez-Montero, L.M. Gómez-Sainero, R.T.Baker, J. Palomar, S. Omar, S. Eser, J.J. Rodriguez, Appl. Catal. B: Environ.162, (2015) 532-543

4. M. Bonarowska, Z. Kaszkur, D. Łomot, M. Rawski, Z. Karpiński, Appl. Catal. B: Environ.162 (2015) 46-56

5. A. Śrębowata, R. Baran, D. Łomot,D. Lisovytskiy, T. Onfroy, S. Dzwigaj, Appl. Catal. B: Environ.147 (2014) 208-220

6. Z.C. Zhang, B.C. Beard, Appl. Catal. A: Gen. 174 (1998) 33-39

7. M. Bonarowska, Z. Kaszkur, L. Kępiński, Z. Karpiński, Appl. Catal. B: Environ.99 (2010) $248-256$ 
8. R. Baran, I. I. Kamińska, A. Śrębowata, S. Dzwigaj, Micropor. Mesopor. Mater. 169 (2013) $120-127$

9. A. Śrębowata, R. Baran, S. Casale, I.I. Kamińska, D. Łomot, D. Lisovytskiy, S. Dzwigaj, Appl. Catal. B: Environ.152-153 (2014) 317-327

10. R, Baran, A. Śrębowata, S. Casale, D. Łomot, S. Dzwigaj, Catal. Today 226 (2014) 134140

11. H. Zea, K.Lester ,A.K. Datye, E. Rightor, R. Gulotty, W.Waterman ,M.Smith, Appl. Catal.A:Gen 282 (2005) 237-245

12. N. Job, B. Heinrichs, F. Ferauche, F. Noville, J. Marien, J-P Pirard Catal. Today 102-103 (2005) 234-241

13. M.C.J. Bradford, M.A. Vannice, Appl. Catal. A: Gen. 142 (1996) 73- 96

14. C.H. Bartholomew, R.B. Pannell, J. Catal. 65 (1980) 390-401

15. J.T. Stuckless, N. Al-Sarraf, C.E. Wartnaby, D.A. King, J. Chem. Phys. 99 (1993) 22022212

16. L. Znak, J. Zieliński, Appl. Catal. A: Gen. 413-414 (2012)132-139

17. J. Dedecek, L. Capek, D. Kaucky, Z. Sobalik, B. Wichterlova, J. Catal. 211 (2002) 198207

18. T. Lehmann, T. Wolff, C. Hamel, P. Veit, B. Garke, A. Seidel-Morgenstern, Micropor. Mesopor. Mater 151 (2012) 113-117

19. J. Shibata, K. Shimizu, Y. Takada, A. Shichi, H. Yoshida, S. Satokawa, A. Satsuma, T. Hattori, J. Catal. 227 (2004) 367-374 
20. K. Sato, T. Yoshinari, K. Kintaichi, M. Haneda, H. Hamada, Appl. Catal. B: Environ.. 44 (2003) 67-78

21. M. Matsuoka, E.Matsuda, K. Tsuji, H. Yamashita, M. Anpo, J. Mol. Catal. A 107 (1996) $399-403$

22. S. Dzwigaj, N. Popovych, P. Kyriienko, J.-M. Krafft, S. Soloviev, Micropor. Mesopor. Mater. 182 (2013) 16-24

23. N. Popovych, P. Kyriienko, S. Soloviev, S. Orlyk, S. Dzwigaj, Micropor Mesopor. Mater. 203 (2015) 163-169

24. D. Chen, Z. Qu, S. Shen, X. Li, Y. Shi, Y. Wang, Q. Fu, J. Wu, Catal. Today 175 (2011) $338-345$

25. R. Baran, Y. Millot, T. Onfroy, F. Averseng, J.-M. Krafft, S. Dzwigaj, Micropor.

Mesopor. Mater. 161 (2012) 179-186,41

26. C.D. Wagner, J. Vac. Sci. Technol. 15 (1978) 518-523

27. P P. Kulkarni, V. I. Kovalchuk, J. L. d'Itri, Appl. Catal. B: Environ. 36 (2002) 299-309

28. S. L. Pirard, J-P Pirard, G. Heyen, J-P Schoebrechts, B. Heinrichs Chem. Eng. Journal 173 (2011) 801-812

29. Y. Han, J. Zhou, W. Wang, H. Wan, Z. Xu, Sh. Zheng, D. Zhu, Appl. Catal. B: Environ. 125 (2012) 172- 179

30. N. S. Babu, N. Lingaiah, Nayeem Pasha, J. Vinod Kumar, P.S. Sai Prasad, Catal. Today, 141 (2009) 120-124

31. S. Gómez-Quero, F. Cárdenas-Lizana , M. A. Keane, J. Catal. 303 (2013) 41-49 


\section{Figure captions:}

Figure 1. DR UV-vis spectra recorded at ambient atmosphere of $\mathrm{C}-\mathrm{Ni}_{2.0} \mathrm{SiBEA}, \mathrm{C}$ $\mathrm{Ag}_{2.0} \mathrm{SiBEA}$ and $\mathrm{C}-\mathrm{Ag}_{2.0} \mathrm{Ni}_{2.0} \mathrm{SiBEA}$ zeolites.

Figure 2. Temperature - programmed reduction profiles of $\mathrm{C}-\mathrm{Ni}{ }_{2.0} \mathrm{SiBEA}, \mathrm{C}-\mathrm{Ag}_{2.0} \mathrm{SiBEA}$ and $\mathrm{C}-\mathrm{Ag}_{2.0} \mathrm{Ni}_{2.0} \mathrm{SiBEA}$ zeolites.

Figure 3a. TEM images and metal nanoparticle size distribution of red-C- $\mathrm{Ag}_{2.0} \mathrm{SiBEA}$ and red-C- $\mathrm{Ag}_{2.0} \mathrm{Ni}_{2.0} \mathrm{SiBEA}$ zeolite catalysts.

Figure 3b. STEM images and EDS-elemental mapping of Ag (violet) and Ni (orange) for red$\mathrm{C}-\mathrm{Ag}_{2.0} \mathrm{Ni}_{2.0} \mathrm{SiBEA}$

Figure 4. Time on stream behavior of red-C-Ni $\mathrm{N}_{2.0} \mathrm{SiBEA}$ red-C- $\mathrm{Ag}_{2.0} \mathrm{SiBEA}$ and red-C$\mathrm{Ag}_{2.0} \mathrm{Ni}_{2.0} \mathrm{SiBEA}$ zeolite catalysts in hydrodechlorination of 1,2-dichloroethane at $523 \mathrm{~K}$ : overall conversion and ethylene selectivity.

Figure 5. XRD results for red-C- $\mathrm{Ag}_{2.0} \mathrm{SiBEA}$, red-C- $\mathrm{Ag}_{2.0} \mathrm{Ni}_{2.0} \mathrm{SiBEA}$, spent-red-C$\mathrm{Ag}_{2.0} \mathrm{SiBEA}$ and spent-red-C- $\mathrm{Ag}_{2.0} \mathrm{Ni}_{2.0} \mathrm{SiBEA}$ zeolite catalysts (circles $-\mathrm{Ag}(0)$ triangles $\mathrm{AgCl})$. 


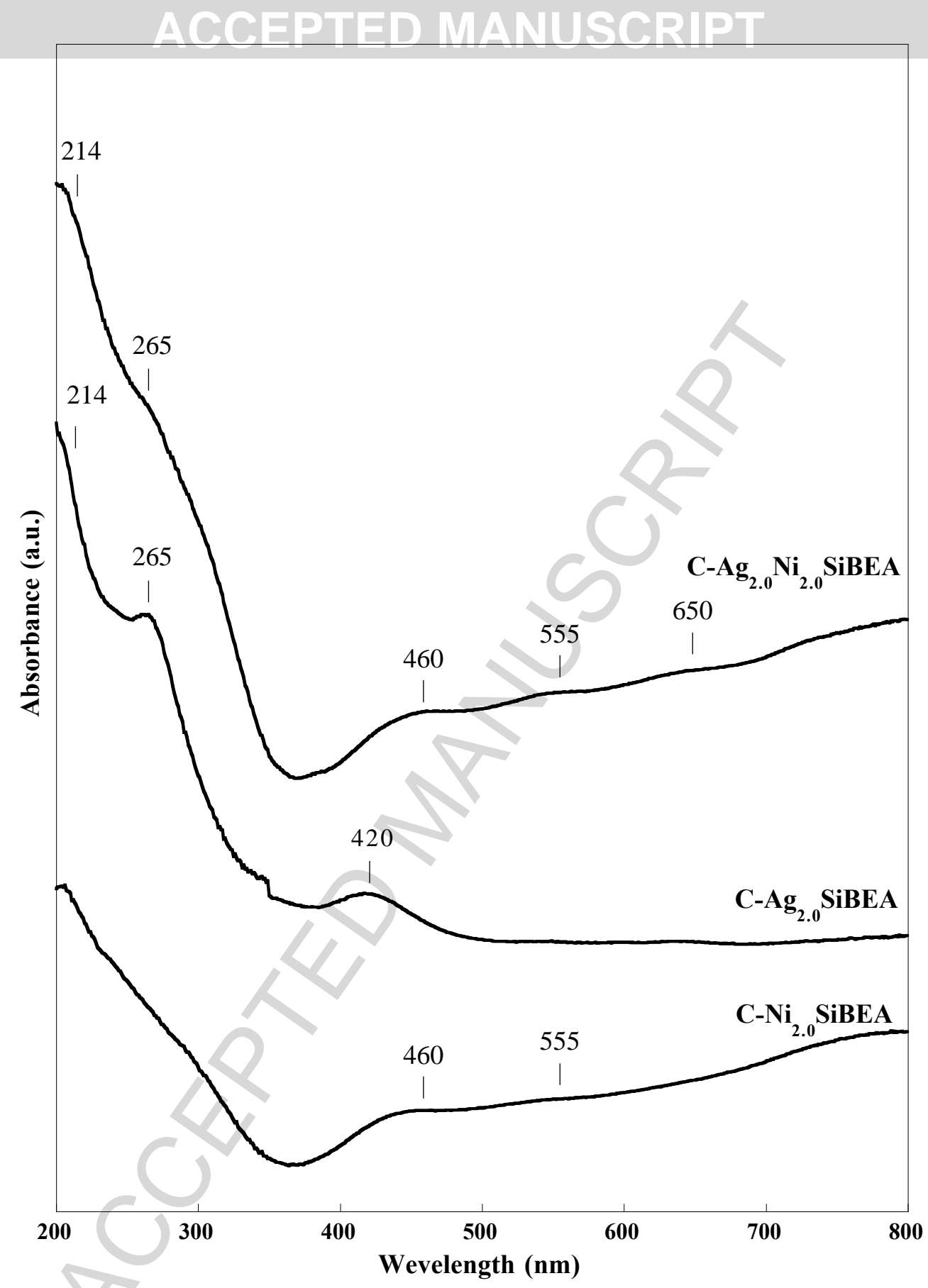

Figure 1 


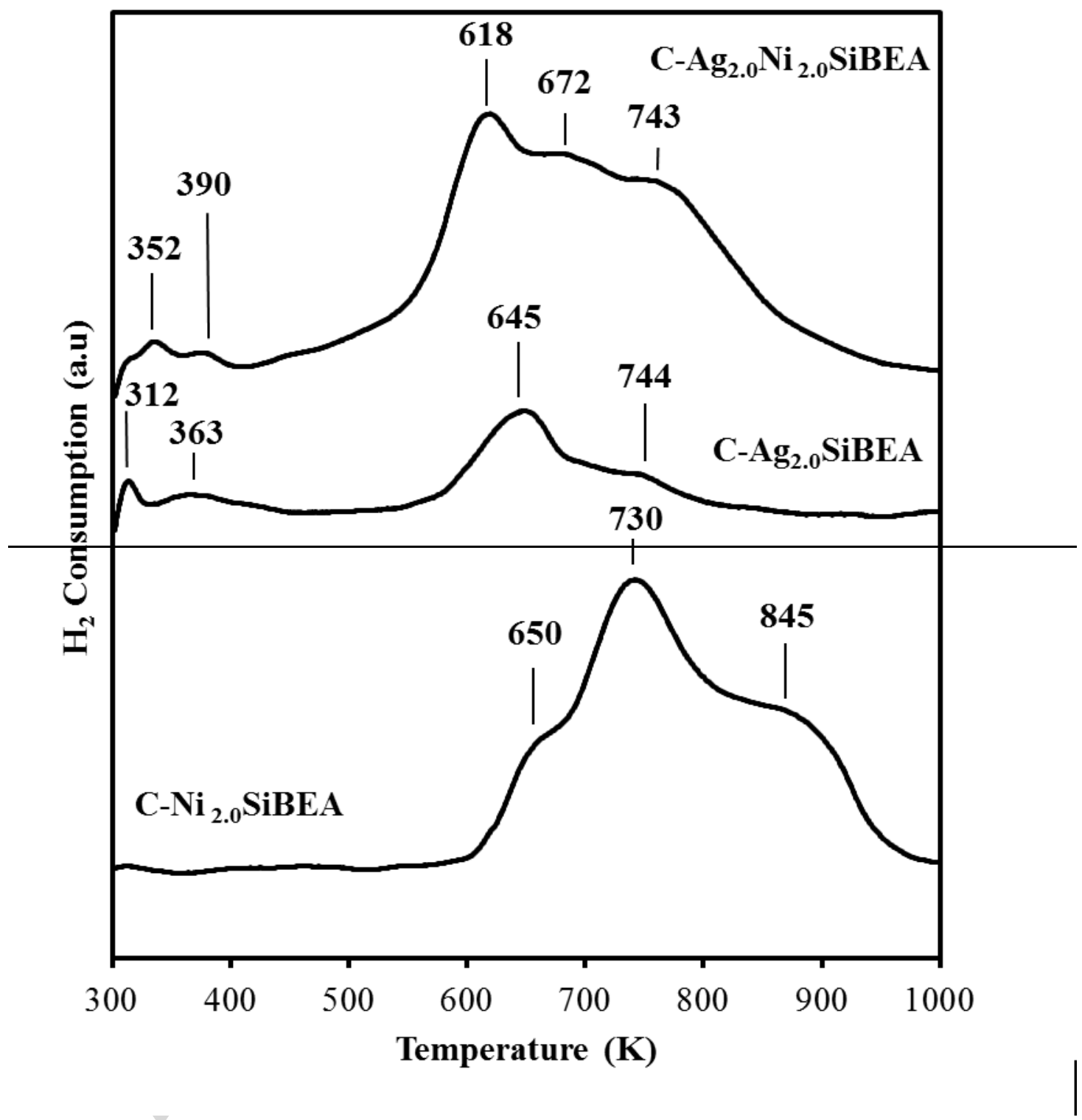

Figure 2 

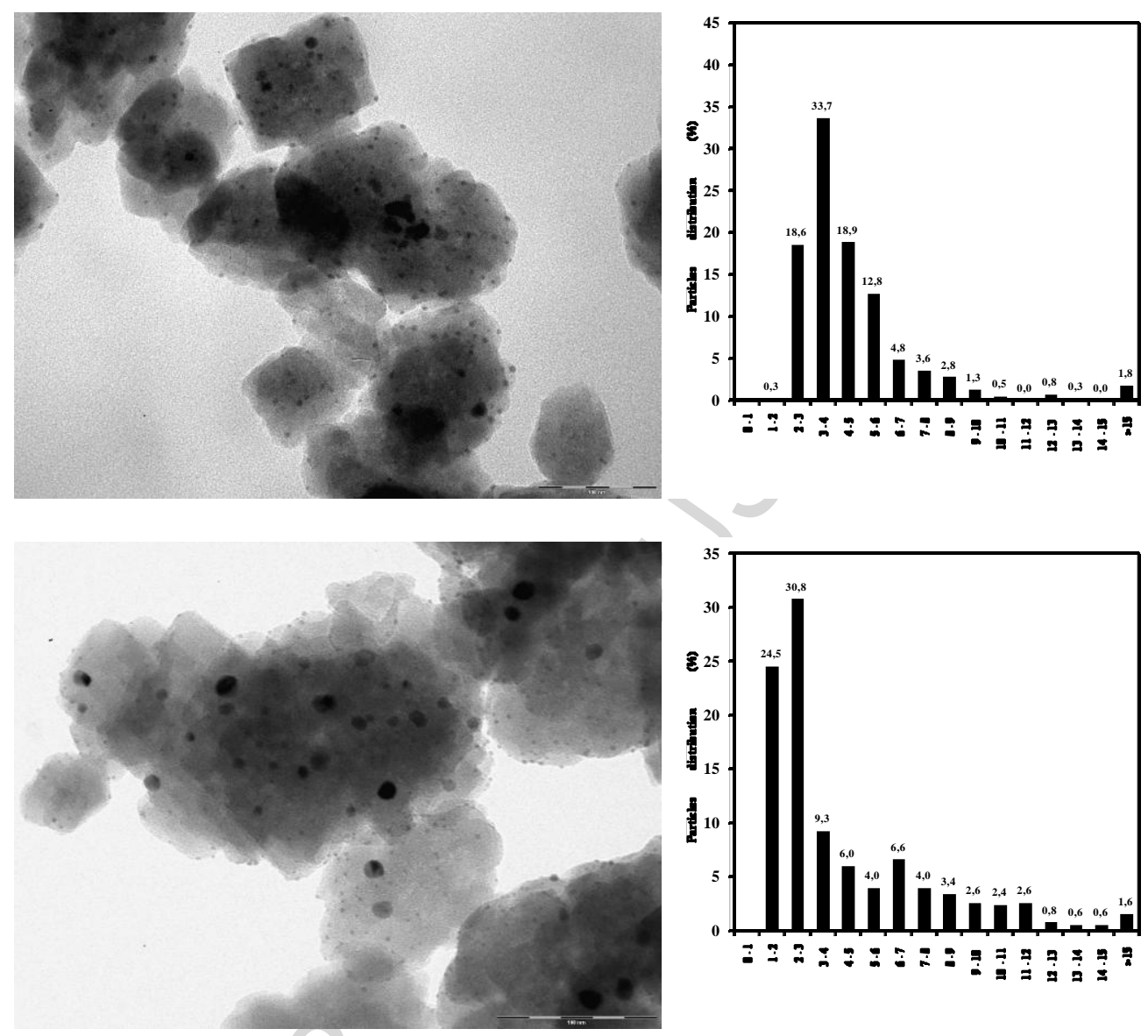

Figure 3a 


\section{ACCEPTED MANUSCRIPT}

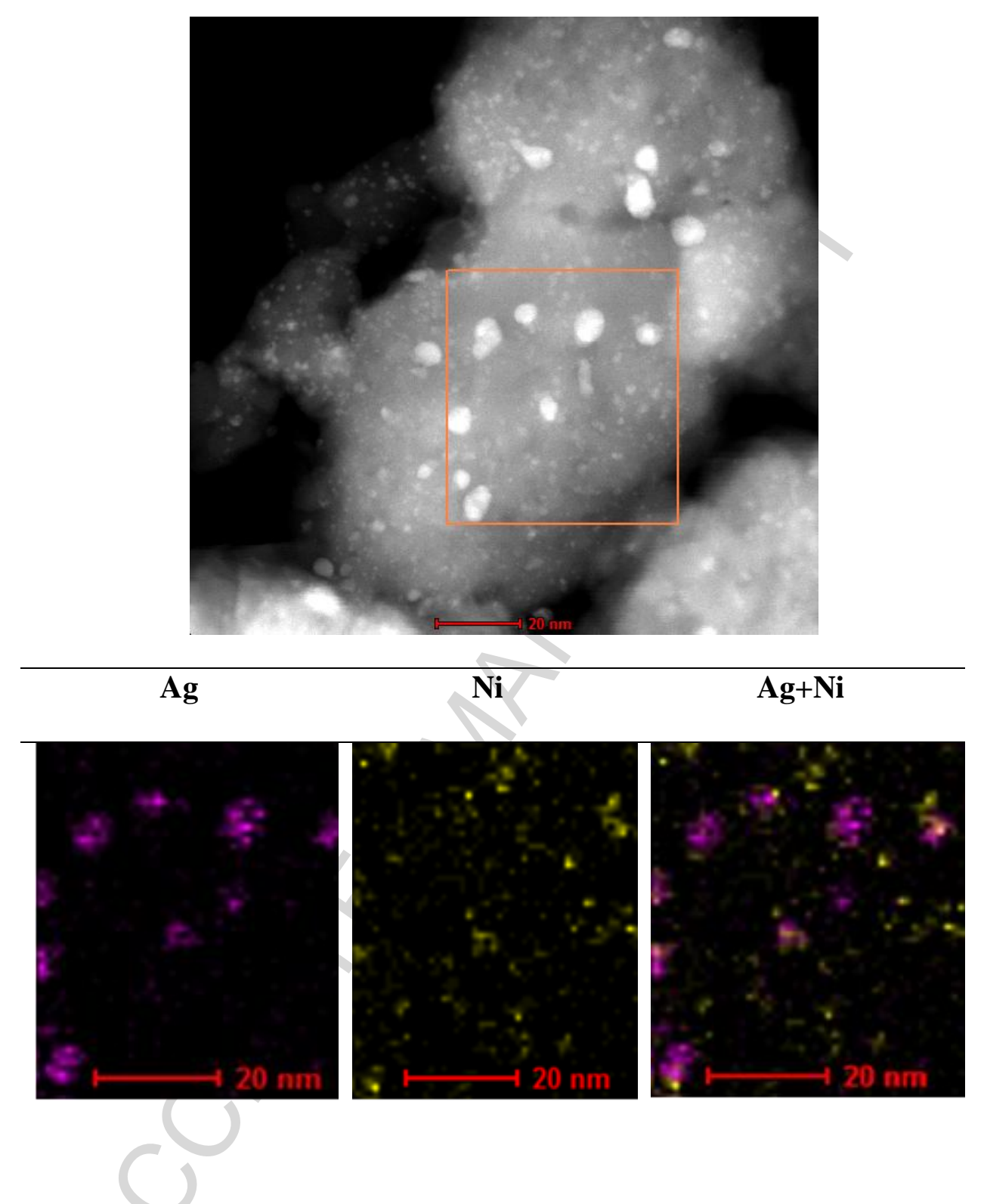

Figure $3 b$ 


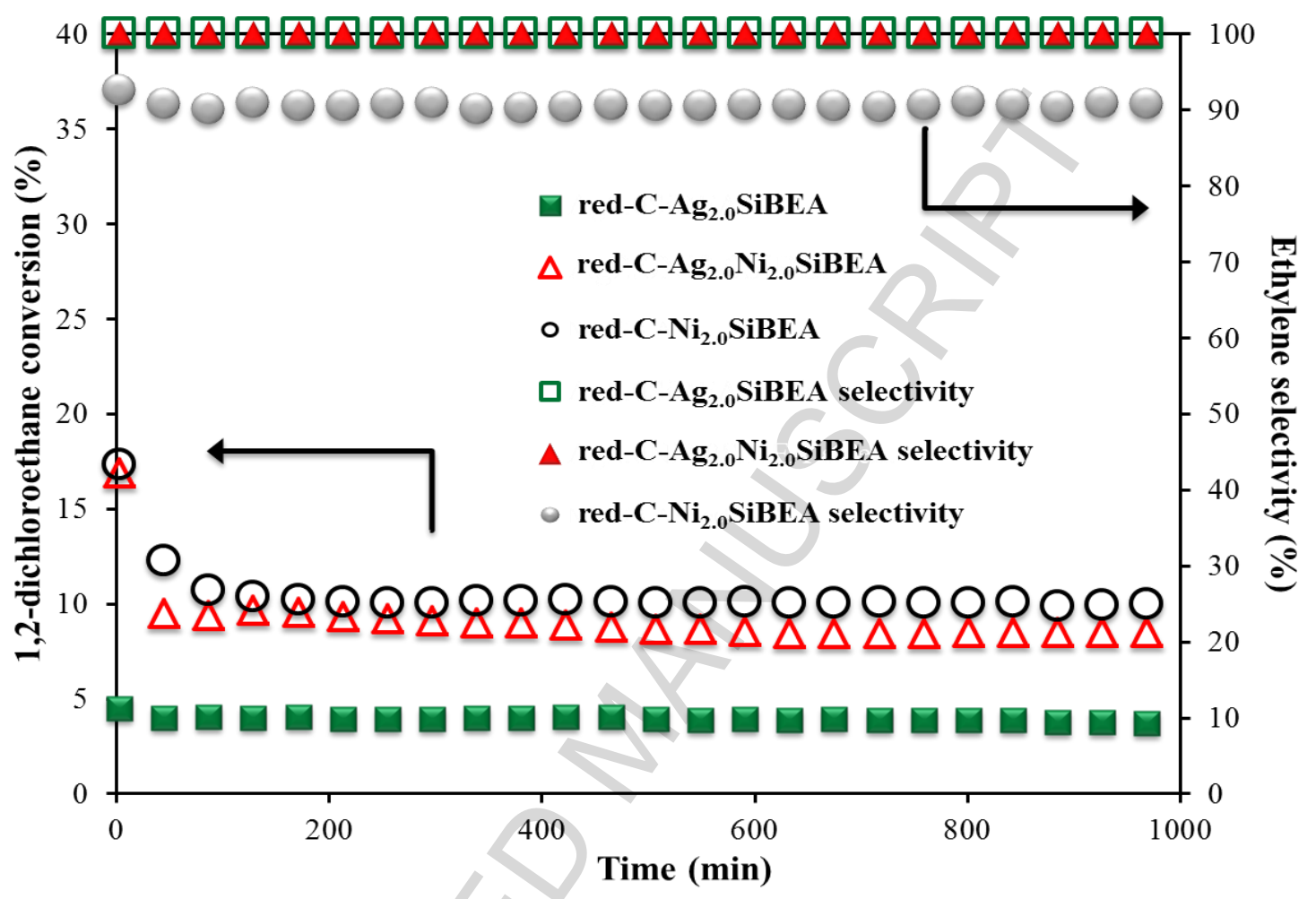

Figure 4 


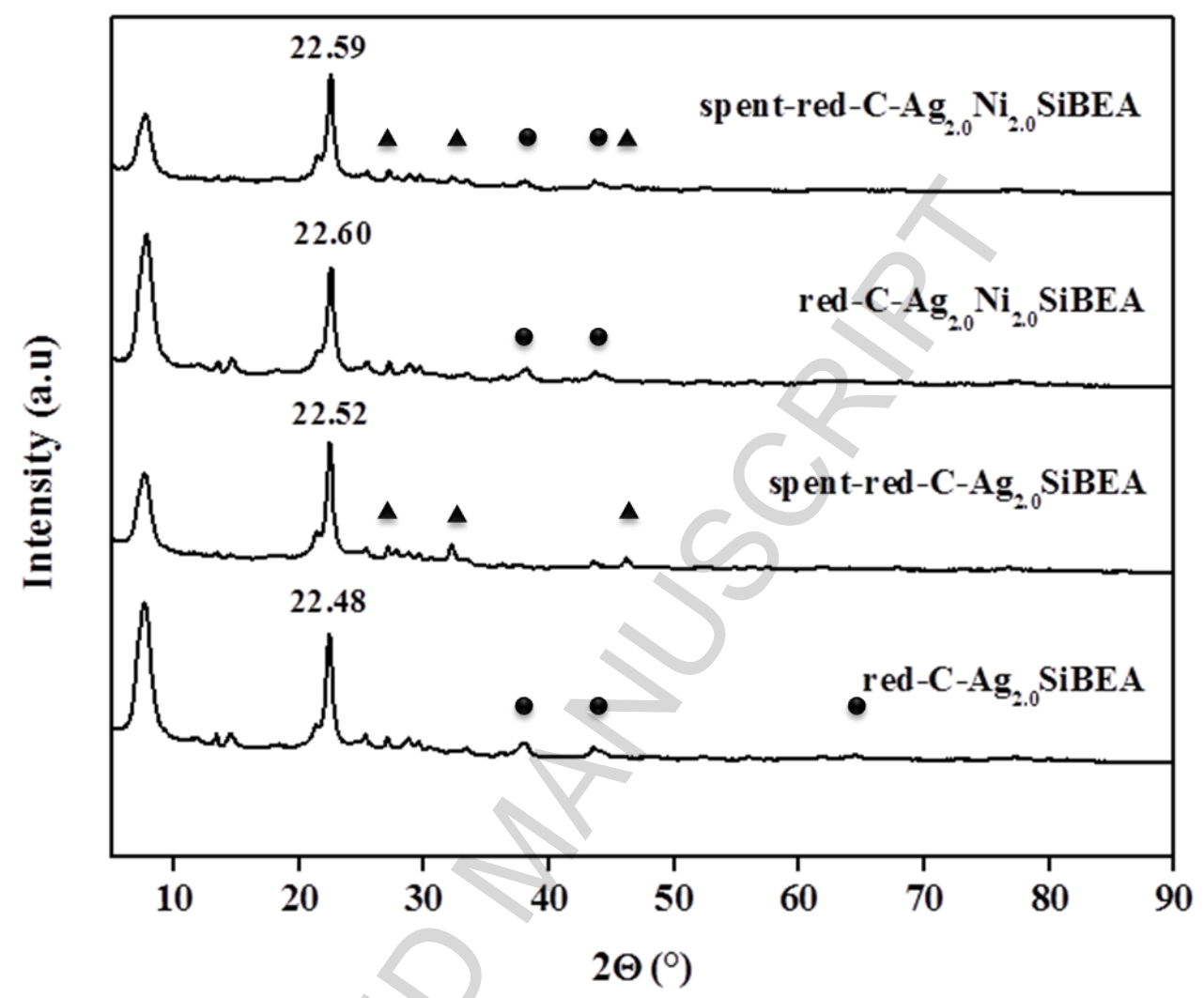

Figure 5 


\section{Graphical Abstract}

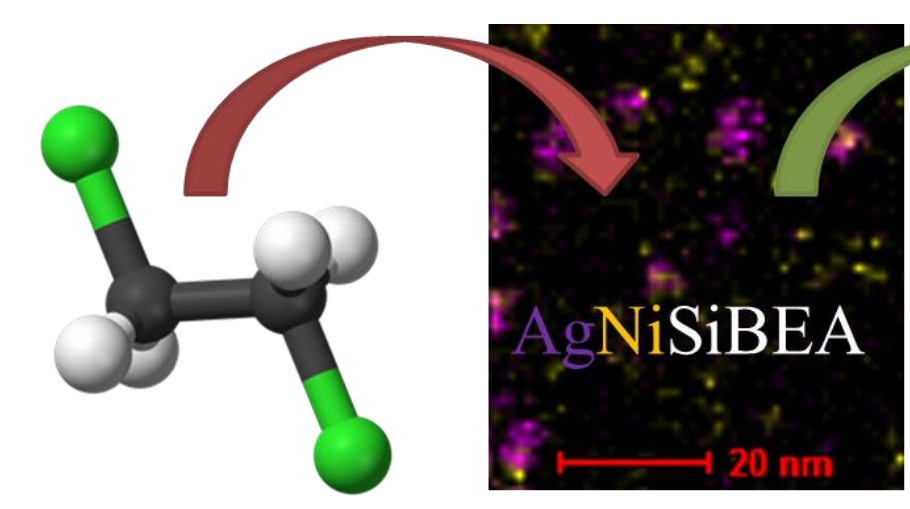

1,2-dichloroethane

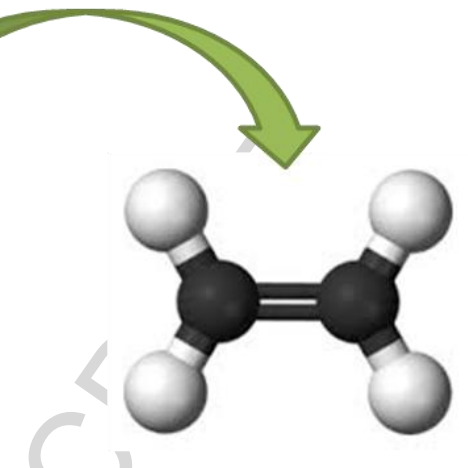

Ethylene 


\section{Highlights}

- Two-step postsynthesis method allowed to obtain catalysts with high metal dispersion.

- HRTEM of Ag-Ni catalyst distinguished separately $\mathrm{Ni}(0)$ and $\mathrm{Ag}(0)$ nanoparticles.

- Ag-Ni-containing catalyst is active in HDC of 1,2-dichloroethane

- Red-C-AgSiBEA and red-C-AgNiSiBEA catalysts showed $100 \%$ selectivity toward ethylene. 